\title{
DO BRAZILIAN SCIENTIFIC JOURNALS PROMOTE THE ADHERENCE OF CHAGAS DISEASE RESEARCHERS TO INTERNATIONAL ETHICAL PRINCIPLES?
}

Guilherme MALAFAIA(1), Dirce GUILHEM(2) \& André TALVANI(3)

\begin{abstract}
SUMMARY
The ethical aspects of the Brazilian publications about human Chagas disease (CD) developed between 1996 and 2010 and the policy adopted by Brazilian medical journals were analyzed. Articles were selected on the SciELO Brazil data basis, and the evaluation of ethical aspects was based on the normative contents about ethics in research involving human experimentation according to the Brazilian resolution of the National Health Council no. 196/1996. The editorial policies of the section "Instructions to authors" were analyzed. In the period of 1996-2012, 58.9\% of articles involving human Chagas disease did not refer to the fulfillment of the ethical aspects concerning research with human beings. In $80 \%$ of the journals, the requirements and confirmation of the information about ethical aspects in the studies of human $\mathrm{CD}$ were not observed. Although a failure in this type of service is still observed, awareness has been raised in federal agencies, educational institutions/research and publishing groups to standardize the procedures and ethical requirements for the Brazilian journals, reinforcing the fulfillment of the ethical parameters, according to the resolution of NHC no. $196 / 1996$
\end{abstract}

KEYWORDS: Ethics in research; Chagas disease; Bioethics.

\section{INTRODUCTION}

Themes and issues related to bioethics have been increasingly discussed at the scholar-scientific Brazilian community. Bioethics is defined as the interdisciplinary examination of the moral and ethical dimensions of human conduct in the areas of life sciences and health $\operatorname{care}^{27}$. Bioethics is the field of applied ethics that has grown the most, and it has been used as a tool in the process of "discussion, enhancement, and consolidation of democracies, citizenships, human rights and social justice"13. The resolution of the National Health Council (NHC) no. 196/1996 ${ }^{1}$ has become a regulatory landmark for Brazilian scientific research involving human experimentation, its development having originated in a long process of analysis of international statements and guidelines about research on human beings, whose main objective is to ensure respect to life ${ }^{34}$. This resolution incorporates several concepts of bioethics and foresees the need for free and informed consent by the participant and the necessity of previous approval of the research protocol by a Research Ethics Committee (REC). Furthermore, under the individual and collectivities view, it also consolidates four basic ethics references: autonomy, nonmaleficence, benefice and justice, and aims to ensure the rights and duties concerning the scientific community, the participants, the state and society at large.

However, despite the growth of discussions related to bioethics and research in this area ${ }^{6,13}$, difficulties and conflicts still exist. Among the problems, the use of poor countries as loci to carry out the studies and development of products can be highlighted ${ }^{14}$; as can the inexistence of a common moral standard to solve controversies that come along with biomedical science and high technologies applied to health ${ }^{5}$ and the disregard of democratic benefit by the research participants ${ }^{13}$ of the benefices created by the scientific and technological development.

Equally important has been the theme related to "bioethics and the publication of the results obtained in research with humans"16,18. Because the Resolution NHC no. 196/1996 does not stipulate editorial rules or publication rules for the studies involving experiments with human beings, there is a concern that many papers are being published in disagreement with the ethical procedures; or at least, that the information related to the fulfillment of these procedures is being omitted in the scientific papers.

Another important issue relates to the role of scientific journals on aspects of fulfillment of the bioethical principles related to human experimentation. Studies have shown a tenuous participation of Brazilian journals in fulfilling the ethical aspects of human research, although more recently an improvement has been perceived $\mathrm{d}^{11,19,20,23,26,30,31,33}$. The journals can contribute to the fulfillment of ethical issues by publishing only studies that satisfy the bioethical standards. In this case, the

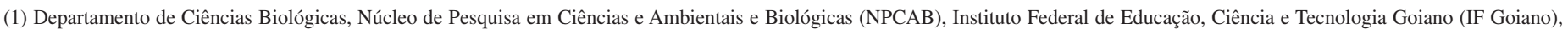
Campus Urutaí, Urutaí, GO, Brazil.

(2) Programa de Pós-Graduação em Enfermagem, Departamento de Enfermagem, Universidade de Brasília, Campus Darcy Ribeiro, Brasília, DF, Brazil.

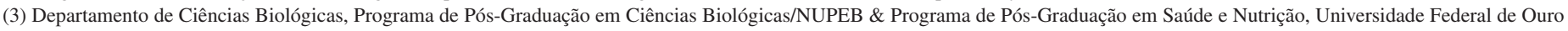
Preto, Ouro Preto, MG, Brazil.

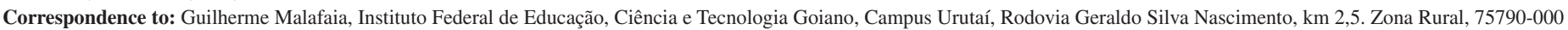
Urutaí, GO, Brasil. Phone: 5564 3465-1946. E-mail: guilhermeifgoiano@ gmail.com 


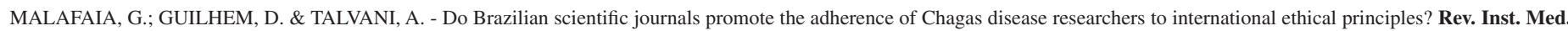
Trop. Sao Paulo, 55(3): 159-65, 2013.

existence of ethical guidelines can assist in the selection of received manuscripts, so that only those who were able to prove the veracity of the information on the ethical aspects involving humans could give input on the editorial process in the journal. When one publication or journal requires compliance from the authors in terms of ethical issues in human research, it is encouraging the dissemination among other researchers of the necessity to develop and publish their results in the light of ethical requirements and measures ${ }^{21}$. The adherence to the ethical standards by editorial policies from journals is essential to the scientific community for following and invigilating rigorously the ethical assumptions from each piece of research. Indeed, these rules should be inserted in "Instructions to authors" or "Author guidelines" in each journal to facilitate the visibility and make them easy to access and query. Internationally, the $30^{\text {th }}$ paragraph of the Helsinki Declaration emphasizes that "Authors, editors and publishers all have ethical obligations with regard to the publication of the results of research. Authors have a duty to make publicly available the results of their research on human subjects and are accountable for the completeness and accuracy of their reports. They should adhere to accepted guidelines for ethical reporting. Negative and inconclusive as well as positive results should be published or otherwise made publicly available. Sources of funding, institutional affiliations and conflicts of interest should be declared in the publication. Reports of research not in accordance with the principles of this Declaration should not be accepted for publication" ${ }^{2,36}$. The International Committee of Medical Journal Editors reports emphasizes the uniform requirements for manuscripts submitted to biomedical journals: "When reporting experiments on human subjects, authors should indicate whether the procedures followed were in accordance with the ethical standards of the responsible committee on human experimentation (institutional and national) and with the Helsinki Declaration of 1975, as revised in 2008. If doubt exists whether the research was conducted in accordance with the Helsinki Declaration, the authors must explain the rationale for their approach and demonstrate that the institutional review body explicitly approved the doubtful aspects of the study". Thus, ethical issues and guidelines on research involving human beings stand out as important protection in order to avoid conflicts in the fields of ethics and health.

An important field to evaluate these bioethical considerations in scientific publications is that involving neglected diseases. "Neglected diseases" are not necessarily diseases of "poor countries" or just of "tropical regions", but those which escape from the attention of policies of research and development of pharmaceutical industries, as they are not profitable in the creation or commerce of medicines. As an example, between 1975 and 2004, only 21 (1.3\%) of 1556 new drugs were developed and approved to be used in those "neglected" diseases ${ }^{4}$, responsible for around $11.4 \%$ of global diseases with high morbidity and mortality rates, besides being associated with the economic underdevelopment of some countries ${ }^{7}$.

In this context, human Trypanosoma cruzi infection stands out. Also known as American trypanosomiasis or Chagas disease (CD), this disease has been described by the Brazilian medical Dr. Carlos Ribeiro Justiniano Chagas ${ }^{3}$. CD affects around eight to 10 million individuals in Latin America, with over 40 million people exposed to the risk of contracting the disease by the insect vector (hematophagous hemiptera), blood transfusion, organ transplantations, laboratory accidents or food intake (accidents with sugar-cane juice and açai juice among others) ${ }^{9}$.
Particularly in Brazil, there is an estimated two to three million T. cruzi infected individuals, with a perspective of 100 new cases every year ${ }^{8,22,28}$.

Since the discovery of human CD in 1909, several pieces of research have been carried out on animal models and on human beings for a better understanding and control of the disease. However, in many countries, the exploitation, coercion and manipulation of free and informed consent under the name "the science of their publications" may still co-exist. In the specific case of human $\mathrm{CD}$, the illness presents important sociocultural and political-economic aspects that involve issues of inequity and globalization, which are often not considered ${ }^{25}$. In this context, the present work aimed to analyze the ethical aspects described in the body of Brazilian scientific papers involving human $\mathrm{CD}$, published in Brazilian periodicals in the years following the resolution NHC no. 196/1996, as well as to analyze the current ethical orientation of Brazilian periodicals about ethics in research. It is assumed that the consideration of ethics in the publication of research results in human beings refers not only to the fulfillment of a regulatory framework, but that it also has educational qualities and contributes to the reflection and construction of a culture of respect and value for the human being.

\section{METHODS}

The present study is an exploratory work of a bibliographic and documental sense. Initially, a search was carried out in the data bank of SciELO Brazil (Scientific Electronic Library Online) (http://www. scielo.br) in order to select the papers involving human CD published by Brazilian medical and biomedical periodicals after the resolution NHC no. 196/1996. Papers were searched year by year (1996 to 2010) using the descriptors "doença de Chagas", "chagas disease", "Trypanosoma cruzi", "tripanossomíase americana" e "American trypanosomiasis".

Papers about studies developed outside of Brazil were excluded, even when they had authors linked to Brazilian institutions, as well as those papers that mentioned CD without the human disease as focus of study, such as papers dealing with studies about the ecological or breeding aspects of the insects or about the general biology of the etiologic agent. Besides, studies involving experimental T. cruzi infection or in vitro experiments were also excluded from this study.

The evaluation of the ethical aspects in the body of the papers was based on the methodology adopted by MALAFAIA et al. ${ }^{21}$. According to the normative content on human research ethics contained in the resolution from NHC no. 196/1996, thirteen items were built in order to evaluate the ethical content of the investigated papers. The items were: i) approval of the study by a Research Ethics Committee (REC); ii) signature of the participants of the study in the Free and Informed Consent Form (FICF); iii) whether obtaining FICF was post-project information; iv) whether participation of the "subject of research" was voluntary; v) whether the participant was informed about the objectives of the research; vi) whether the participant was informed about the benefits of the research; vii) whether the participant was informed about the risks of the research; viii) whether the risks of the research were described in the paper; ix) whether the study was conducted in accordance with the principles of the Helsinki Declaration; $x$ ) whether the study was conducted in accordance with Brazilian resolution NHC no. 196/1996; xi) whether the study was performed after consent of the local health authorities in the development of research; xii) whether the survey results 
were forwarded to participants and finally, xiii) whether in the paper the protocol number of the project provided by a REC was presented.

To simplify the analysis of data, the decision was made to attribute to the evaluated paper a score of 1 for each piece of information present in its body and a score of 0 when the information was absent. Through this methodology, it was possible to investigate not only the quantity of papers mentioning the fulfillment of ethical aspects, but also the amount of information given in each text.

After the evaluation of the selected papers, the ethical content present on editorial rules of the Brazilian periodicals that published papers directly involving human CD after the resolution NHC no. 196/1996 was investigated. The intention was to verify if such periodicals presented, by their guidelines, requirements for the fulfillment of the ethical guidelines dealing with studies in human beings as a pre-requisite for publication. To access this information the homepages of all journals were visited, and the section "Instruction to Authors" (considered, in some cases, the only way of communication between the researchers and the editors) was evaluated according to previously informed methodologies ${ }^{11,21,33}$. At the time, the ethical orientations of the journals were evaluated, as well as the way in which publishers demanded veracity of the ethical information presented by the authors upon submitting their study. The data was systematized and evaluated with the intention to support a discussion about the ethics in the Brazilian scientific publications.

\section{RESULTS}

After consulting the papers in the data bank of SciELO Brazil, 285 papers were selected according to the descriptor "doença de Chagas", 378 to the descriptor "Chagas disease", 394 to "Trypanosoma cruzi", two to "tripanossomiase americana", and two to "American trypanosomiasis", totaling 1061 papers. After applying the previously described criteria of exclusion and the possible duplicity of works, 158 papers were selected for analysis. As observed in Figure 1, the number of papers published yearly did not present uniformity, with a higher number of publications in 2010. Concerning the category of published papers throughout the period of analysis, a higher percentage was inserted into the category "original paper".
According to the evaluated papers, the Revista da Sociedade Brasileira de Medicina Tropical (RSBMT), the Arquivos Brasileiros de Cardiologia (ABC) and Cadernos de Saúde Pública (CSP) were those periodicals that most published studies directly involving human $\mathrm{CD}$ in the time frame of this investigation (Table 1). These Brazilian journals were responsible for the publication of over two thirds of the human CD papers selected for analysis.

Concerning the evaluation of the ethical aspects contained in the body of the papers analyzed, an increase was observed in the average of the scores attributed to each journal, within the time frame of this study (Fig. 2A). In the period 1996-2000, few papers had any kind of reference to the fulfillment of ethical aspects, whereas this number increased in the period 2009-2012.

However, upon analysis of the percentage of papers which presented at least one piece of information concerning the study approved by a REC (information "i", Frame 1), less than half of the papers published by those journals that most published about human CD in Brazil (RSBMT - $43.9 \%, \mathrm{ABC}-47.4 \%$ and $\mathrm{CSP}-33.3 \%$ ) mentioned this information (Fig. 2B). In a global evaluation, which does not consider the proportional analysis of the publications during the period of study and the papers published by periodicals, it could be observed that $58.9 \%(n=93)$ of them had no reference to the fulfillment of the ethical aspects related to research with human beings (score 0 ).

Concerning the evaluation of the ethical orientations offered by Brazilian journals that published studies on human CD, 19 (76\%) informed in their "Instructions to Authors" sections that the submitted study needed previous approval of a REC. Four periodicals $(16 \%)$ suggested to the authors to read documents about ethical issues and offered the readings of some parts or full documents which regulated research involving human beings. Five periodicals (20\%) highlighted in their instructions the need to use the FICF and offered the readings of the ethical guidelines of uniform requirements for manuscripts submitted to biomedical publications.

On the other hand, only 13 periodicals $(52 \%)$ clearly indicated that the information about the ethical aspects of research involving human

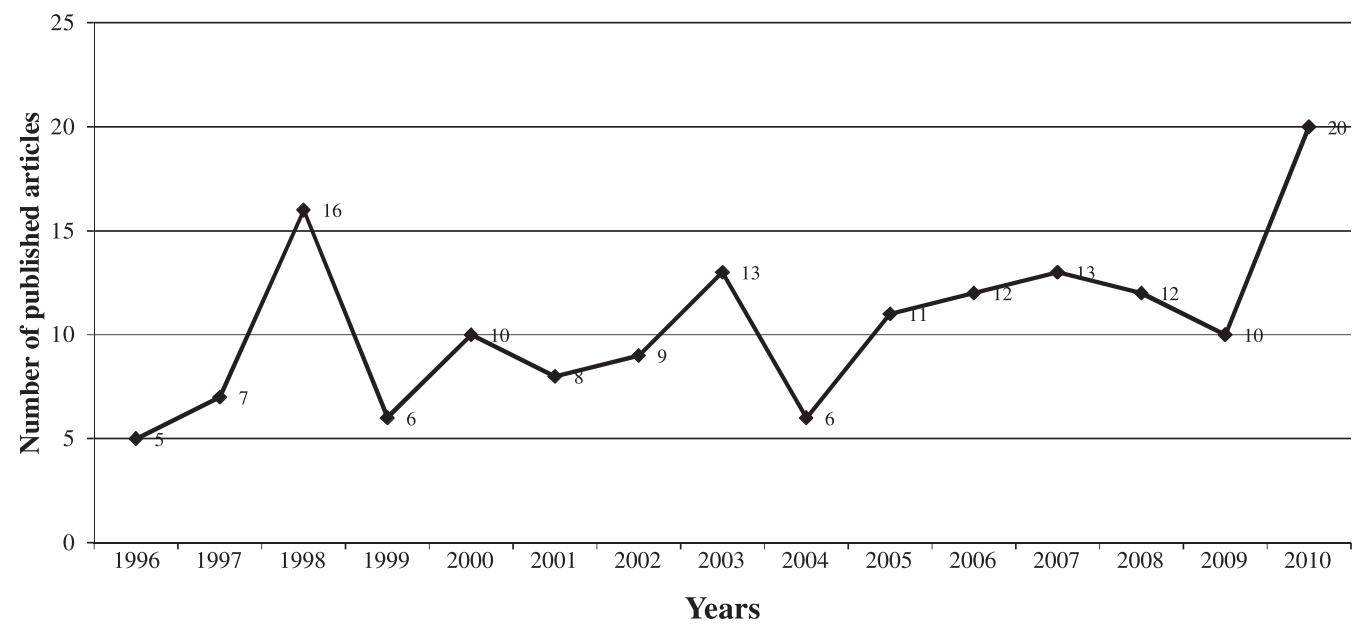

Fig. 1 - Number of Brazilian publications indexed by SciELO Brazil on human Chagas disease evaluated in the period of 1996 to 2010. 
MALAFAIA, G.; GUILHEM, D. \& TALVANI, A. - Do Brazilian scientific journals promote the adherence of Chagas disease researchers to international ethical principles? Rev. Inst. Med. Trop. Sao Paulo, 55(3): 159-65, 2013.

Table 1

Number of articles published by SciELO about human Chagas disease from 1996 to 2010 per journal

\begin{tabular}{|c|c|c|c|c|c|c|c|c|c|c|c|c|c|c|c|c|}
\hline Journals & $\stackrel{2}{2}$ & $\hat{a}$ & $\stackrel{\infty}{\stackrel{2}{\Xi}}$ & ळ & 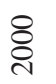 & $\bar{\delta}$ & ర్రి & $\overbrace{i}$ & 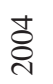 & 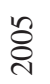 & ঠ্ণ & 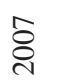 & 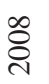 & ஓे & 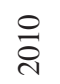 & ت్ّ \\
\hline Rev Soc Bras Med Trop & - & 5 & 6 & 5 & 6 & 5 & 7 & 8 & 1 & 7 & 6 & 6 & 8 & 1 & 11 & 82 \\
\hline Arq Bras Cardiol & - & 1 & 3 & - & - & - & - & - & 1 & 2 & 3 & 4 & 1 & - & 4 & 19 \\
\hline Cad Saúde Pública & - & - & 3 & - & - & - & 2 & - & - & 1 & 1 & 3 & - & 2 & - & 12 \\
\hline Mem Inst Oswaldo Cruz & 1 & 1 & 1 & - & - & 1 & - & 1 & - & - & - & - & - & 1 & - & 6 \\
\hline Rev Inst Med Trop Sao Paulo & 2 & - & - & 1 & 1 & 1 & - & 1 & - & - & - & - & - & - & - & 6 \\
\hline Rev Bras Hematol Hemoter & - & - & - & - & - & - & - & - & - & - & 1 & - & 1 & 2 & 1 & 5 \\
\hline Arq Neuro-Psiquiatr & 2 & - & 1 & - & - & - & - & - & - & - & - & - & - & 1 & - & 4 \\
\hline Rev Saúde Pública & - & - & 1 & - & 1 & - & - & 2 & - & - & - & - & - & - & - & 4 \\
\hline Rev Col Bras Cir & - & - & - & - & - & - & - & 1 & 1 & - & - & - & - & 1 & - & 3 \\
\hline Acta Cir Bras & - & - & - & - & - & - & - & - & - & - & - & - & 1 & - & 1 & 2 \\
\hline Arq Gastroenterol & - & - & - & - & 1 & - & - & - & - & - & - & - & - & - & - & 1 \\
\hline Arq Bras Cir Dig & - & - & - & - & - & - & - & - & - & - & - & - & - & - & 1 & 1 \\
\hline Arq Bras Oftalmol & - & - & - & - & 1 & - & - & - & - & - & - & - & - & - & - & 1 \\
\hline Braz Arch Biol Technol & - & - & - & - & - & - & - & - & - & 1 & - & - & - & - & - & 1 \\
\hline Braz J Med Biol Res & - & - & - & - & - & - & - & - & 1 & - & - & - & - & - & - & 1 \\
\hline Ciênc Saúde Coletiva & - & - & - & - & - & - & - & - & - & - & - & - & 1 & - & - & 1 \\
\hline J Bras Pneumol & - & - & - & - & - & - & - & - & 1 & - & - & - & - & - & - & 1 \\
\hline Rev Assoc Med Bras & - & - & 1 & - & - & - & - & - & - & - & - & - & - & - & - & 1 \\
\hline Rev Bras Cir Cardiovasc & - & - & - & - & - & - & - & - & 1 & - & - & - & - & - & - & 1 \\
\hline Rev Esc Enferm & - & - & - & - & - & - & - & - & - & - & - & - & - & 1 & - & 1 \\
\hline Rev Bras Reumatol & - & - & - & - & - & - & - & - & - & - & - & - & - & 1 & - & 1 \\
\hline Rev Soc Bras Fonoaudiol & - & - & - & - & & - & - & - & - & - & - & - & - & - & 1 & 1 \\
\hline Rev Hosp Clin & - & - & - & - & - & 1 & - & - & - & - & - & - & - & - & - & 1 \\
\hline Rev Gaúcha Enferm & - & - & - & - & - & - & - & - & - & - & - & - & - & - & 1 & 1 \\
\hline$\underline{\text { São Paulo Med J }}$ & - & - & - & - & - & - & - & - & - & - & 1 & - & - & - & - & 1 \\
\hline
\end{tabular}

Total

beings must be mentioned in the full text upon manuscript submission. Only four (16\%) demanded letters or signed documents by the author(s) stating the fulfillment of ethical aspects. One journal (4\%) requested a copy of the document of consent grant from the subjects involved in the research, and only five (20\%) demanded a copy of the authorization/ approval of the REC.

\section{DISCUSSION}

Before the high incidence of parasite related diseases on the planet responsible for the mortality of an effective part of its population, medical and biomedical research drew special attention to the scope of bioethics ${ }^{35}$. There is encouragement by the scientific institutions or government institutions to figure out the magnitude of these illnesses, and then propose some actions to combat them ${ }^{12}$. However, some researchers, while broadening the possibilities of control and treatment of these diseases, also arouse concerns about the procedures of interrelation among interests of researchers, financial supporting entities and volunteer participants; particularly when there is a possibility that the proposed procedure could hurt, in part, ethical principles ${ }^{17}$.

In Brazil, due to the relative financial boost to develop research related to neglected diseases and the encouragement from research institutions, an increase in studies and scientific publications in a greater diversity of Brazilian journals can be noted, information sustained by this present study and by others involving tropical diseases such as tuberculosis and human visceral leishmaniasis ${ }^{17,21}$. In fact, Brazil comes second highest in the world for the number of submitted studies for publications related to neglected diseases, including human $\mathrm{CD}$, and they are produced in Brazilian universities and research institutes ${ }^{15}$. In the present study, we 

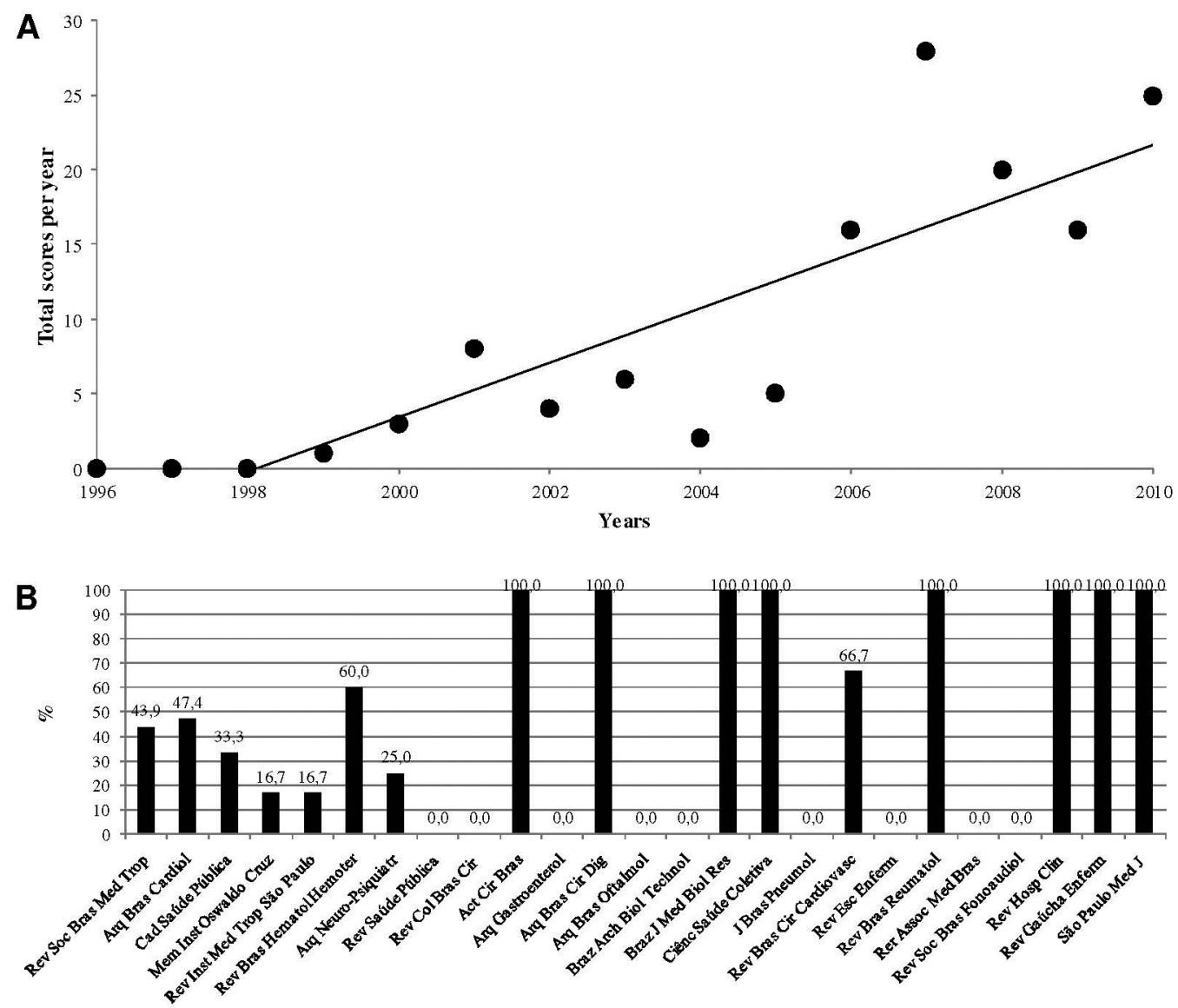

Journals

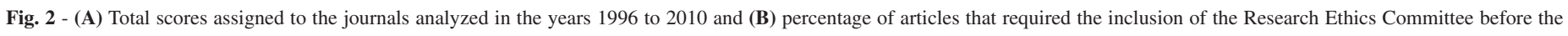
beginning of the study, distributed by paper.

observed an increase in research on human CD developed in Brazil and published in Brazilian periodicals. This was probably a reflection of the high quality and the increase in impact factor and visibility of Brazilian periodicals at an international level, which has been observed in recent years ${ }^{29}$. It was observed that 25 different periodicals published studies related to human CD in the last 15 years (1996 to 2010), especially the periodicals RSBMT, ABC and CSP.

Concerning the ethical aspects explicated in the body of papers published by Brazilian journals, there was an improvement in exposing the fulfillment of these ethical aspects in studies on human CD, especially in the period 2009-2012. It is acceptable that the first few years following enforcement of any new legislation are characterized by a transition period comprised of a stage of assimilation and another of acceptance of the new guidelines. With this in mind, we can partially justify the data observed in the distinct frames of four-year periods after resolution NHC no. 196/1996 (1996 - 1999 and 2000 - 2003).

Similar data were reported by MALAFAIA et al. ${ }^{21}$ in a study on the ethical aspects contained in the publications about human visceral leishmaniasis, other extremely neglected disease. As discussed by the authors, the improvement in the exposure of ethical aspects in the body of such publications is related to, among other aspects, a better assimilation and understanding by the researchers of the importance of the fulfillment of ethical aspects of researches involving human beings. It is noteworthy that the release of funds by financial agencies occurs only after the presentation of the approval document emitted by a REC. This fact certainly encourages the submission of projects to a REC. Furthermore, such improvement could be related to the growing concern of research institutions in demanding from their researchers that protocols of research involving human beings are evaluated by a REC. Moreover, the National Commission on Ethics in Research (CONEP from the Portuguese), linked to NHC, has been acting in this context by updating the guidelines and rules of protection of research subjects in Brazil. In addition, the CONEP provides accreditation and monitoring of the REC network of medical research and educational institutions in the country.

The relevance of the REC in the scientific publications lies on the fact that they carry out an evaluation based on the qualification of the research projects, the experience of the research team involved, the evaluation of the risk/benefit ratio involved, the precise and detailed information to the subject of the research, and consequently, on the grant of his/her consent and the previous evaluation of possible harmful 
MALAFAIA, G.; GUILHEM, D. \& TALVANI, A. - Do Brazilian scientific journals promote the adherence of Chagas disease researchers to international ethical principles? Rev. Inst. Med. Trop. Sao Paulo, 55(3): 159-65, 2013.

effects to the subjects, derived from the proposed study ${ }^{24}$. To facilitate control and registration of research involving humans, since 2012, Brazil adopted an online system named Brazil Platform (www.saude. gov.br/plataformabrasil). This platform is a unified national basis to record-research involving humans for the entire system REC/CONEP. Brazil Platform allows searches to be accompanied at different stages - from submission to final approval of projects by the REC, and by CONEP when needed - including enabling the monitoring of the field phase and sending interim reports and final reports about research (when completed). Highlighting that scientific publication is the result of the finalization of a process, whose start occurs invariably with a research protocol which is therefore an intrinsic part of the production of scientific knowledge.

However, in spite of the improvement observed in the description of the ethical aspects related to publications involving human CD in Brazilian journals, one must always seek the highest level concerning the fulfillment of ethical requirements in human studies. Unfortunately, there are studies on the literature pointing to flaws in the reporting information about the ethical issues in the development of research involving human beings ${ }^{10,32}$.

It is important to emphasize that the analysis before the implementation of the research project is essential for defining the requirements for the ethical conduct of research. However, as the "monitoring" of the study is done by sending partial and final reports, it is not possible to guarantee the ethics in the implementation process, the conduction and the finalization of the research (including interpretation bias, etc.).

Regarding the ethical approach to the editorial guidelines of the journals that published research on human $\mathrm{CD}$, our data evidenced the absence of a description of the fulfillment of ethical aspects in the body of the text in more than half of the evaluated papers, probably relating this fact to the non-requirement by the periodicals. Despite $76 \%$ of the publications having informed that the submitted study must present previous approval by a REC (at least the number of registry of the research and the name of the REC that approved the study), $48 \%$ of the journals did not indicate in their instructions the necessity to include this information in the manuscript.

Out of the three periodicals responsible for more than two thirds of the publications in human CD studies between 1996 and 2010 (RSBMT, ABC and CSP) only CSP stipulated in its "Instructions to Authors" that the papers presenting results of human researches must have a clear statement of this fulfillment in its "Methodology" section.

It turns out to be important for the Brazilian scientific production that the editorial guidelines of national biomedical periodicals remain in accordance with the ethical guidelines contained in the resolution NHC no. 196/1996, even though this normative does not have specifications regarding editorial rules for scientific studies. With this accordance, it is possible that there will be a reduction in Brazilian papers on human CD publications or other parasite-related diseases that still neglect basic information about the ethics involved in the studies. In addition, we emphasize the need for journals that present the enlightening of ethical orientations to enforce their editorial policies, so as to continue adopting procedures that corroborate to only publish studies conducted with ethical principles.

\section{CONCLUDING REMARKS}

There was some improvement in the description of the fulfillment of ethical aspects published about human CD from 1996 to 2010. However, facing the international and Brazilian recommendations about bioethics, and considering that scientific journals may contribute to the improvement (technical quality of the paper and preservation of ethical issues), a review is suggested of the "Instructions to Authors" regarding the obligation to present the approval report of the research involving human studies. Such a requirement is fundamental, especially in research dealing with neglected diseases to protect the rights of the research participants. Furthermore, it is necessary that Brazilian researchers have previous knowledge of the resolution NHC no. 196/1996 and do not only use their technical and scientific knowledge. Particularly in those studies involving parasite related diseases (e.g. Chagas disease), knowledge in bioethics must be a priority request in order to preserve the patient's values, essential to scientific research and to human life.

\section{RESUMO}

\section{Periódicos científicos brasileiros promovem a adesão de pesquisadores em doença de Chagas a princípios éticos internacionais?}

Foram analisados os aspectos éticos das publicações brasileiras sobre a doença de Chagas humana desenvolvidas entre 1996 e 2010 e avaliadas as políticas editoriais dos periódicos médicos brasileiros sobre ética em pesquisa. Os artigos foram selecionados do banco de dados da SciELO Brasil. A avaliação dos aspectos éticos foi baseada nos conteúdos normativos sobre ética envolvendo pesquisa com seres humanos, conforme Resolução brasileira do Conselho Nacional de Saúde - CNS 196/1996. A política editorial dos periódicos foi analisada utilizando-se a seção "Instrução aos autores". No período de 1996-2012, $58,9 \%$ dos estudos envolvendo DC humana não informaram no texto sobre o cumprimento dos aspectos éticos, em relação à pesquisa com seres humanos. Em $80 \%$ dos periódicos avaliados o requerimento e confirmação das informações sobre os aspectos éticos nos estudos sobre a DC humana não foram observados. Apesar de haver ainda lacunas nesse tipo de citação conforme foi observado, tem-se verificado uma conscientização pelos órgãos federais, instituições de ensino/pesquisa e grupos editoriais para padronizar os procedimentos e orientações éticas por parte dos periódicos brasileiros, reforçando o cumprimento dos pressupostos éticos preconizados pela resolução CNS 196/1996.

\section{ACKNOWLEDGEMENTS}

We recognize the financial support of Conselho Nacional de Desenvolvimento Científico e Tecnológico (CNPq). A.T. is a recipient of the productivity award from CNPq.

\section{REFERENCES}

1. Brasil. Resolução 196/96. Diretrizes e normas regulamentadoras de pesquisas envolvendo seres humanos. Conselho Nacional de Saúde. [Cited: 2012 Sept 7]. Available from: $<$ http://conselho.saude.gov.br/comissao/conep/resolucao.html>

2. Carlson RV, Boyd KM, Webb DJ. The revision of the Declaration of Helsinki: past, present and future. Br J Clin Pharmacol. 2004;57: 695-713. 

Trop. Sao Paulo, 55(3): 159-65, 2013.

3. Chagas C. Nova tripanossomíase humana: estudos sobre a morfologia e o ciclo evolutivo do Schizotrypanum cruzi $n$. gen., n. sp., agente etiológico de nova entidade mórbida do homem. Mem Inst Oswaldo Cruz. 1909;1:159-218.

4. Chirac P, Torreele E. Proportion of new drugs developed over the period from 1975 to 2004 that were for neglected tropical diseases and tuberculosis. Lancet. 2006;12:1560-1.

5. Clotet J. Por que bioética? Rev Bioética. 1993;1:13-9.

6. Cohen C, Vianna JAR, Battistella LR, Massad E. Time variation of some selected topics in bioethical publications. J Med Ethics. 2008;34:81-4.

7. Conteh L, Engels T, Molyneux DH. Socioeconomic aspects of neglected tropical diseases. Lancet. 2010;375:239-47.

8. Coura JR, Dias JC. Epidemiology, control and surveillance of Chagas disease: 100 years after its discovery. Mem Inst Oswaldo Cruz. 2009;104(Suppl 1): 31-40.

9. Dias JC, Amato Neto V, Luna EJ. Mecanismos alternativos de transmissão do Trypanosoma cruzi no Brasil e sugestões para sua prevenção. Rev Soc Bras Med Trop. 2011;44: $375-9$.

10. Dingemmann J, Dingemann C, Ure B. Failure to report ethical approval and informed consent in paediatric surgical publications. Eur J Pediatr Surg. 2011;21: 215-9.

11. Fernandes MR, Queiroz MCCAM, Moraes MR, Barbosa MA, Sousa ANL. Ethical standards adopted by Brazilian journals of medical specialties. Rev Assoc Med Bras. 2011;57:267-71.

12. Galvão MTG, Pereira MLD, Barroso MGT. Avaliação ética de projetos de pesquisa de enfermagem no contexto das doenças infecciosas. Texto Contexto Enferm. 2005; $14: 44-8$

13. Garrafa V. Novas fronteiras bioéticas: ética no mundo globalizado - uma perspectiva do Brasil. Rev Port Bioética. 2008;6:279-90.

14. Guilherm D, Squinca FA. Educação em ética na pesquisa: desafio para a formação de jovens cientistas. Brasília Med. 2009;46(Supl 1):3-5

15. Hotez PJ, Aksoy S. PLoS Neglected Tropical Diseases: two years of providing access to innovation for the world's poor and counting. PLoS Negl Trop Dis. 2009;3:e494

16. Johnson JT. The ethics of medical publication. Laryngoscope. 2011;121:1132-6.

17. Kritski AL, Villa TS, Trajman A, Lapa-e-Silva JR, Medronho RA. Ruffino-Netto A. Duas décadas de pesquisa em tuberculose no Brasil: estado da arte das publicações científicas. Rev Saúde Pública. 2007;41(Supl 1):9-14.

18. Malafaia G, Rodrigues ASL. Um comentário sobre a bioética e a publicação de estudos envolvendo a experimentação humana. SaBios Rev Saúde Biol. 2011;6:67-73.

19. Malafaia G, Castro ALS, Rodrigues ASL. Abordagem ética acerca das pesquisas envolvendo seres humanos nas diretrizes editoriais de periódicos brasileiros da área ecologia e meio ambiente. Rev Saúde Pesquisa. 2011;4:321-8.

20. Malafaia G, Rodrigues ASL, Talvani A. The ethical issues of research involving human beings contained in the editorial guidelines of Brazilian medical journals. Arq Bras Ciên Saúde. 2010;35:188-95.
21. Malafaia G, Rodrigues ASL, Talvani A. Ethics in the publication of studies on human visceral leishmaniasis in Brazilian periodicals. Rev Saúde Pública. 2011;45:166-72.

22. Martins-Melo FR, Alencar CH, Ramos AN Jr, Heukelbach J. Epidemiology of mortality related to Chagas' disease in Brazil, 1999-2007. PLoS Negl Trop Dis. 2012;6(2):e1508.

23. Moro JV, Rodrigues JSM, André SCS. A pesquisa envolvendo seres humanos nas instruções aos autores em revistas científicas nacionais de enfermagem. Rev Bioética. 2011;19:543-52.

24. Muccioli C, Dantas PEC, Campos M, Bicas HEA. Relevância do Comitê de Ética em Pesquisa nas publicações científicas. Arq Bras Oftalmol. 2008;71:773-4.

25. Prata A, Dias JC, Coura JR. Os primórdios da doença. Rev Soc Bras Med Trop. 2011;44(Suppl 2):6-11.

26. Pellizzon RF, Montero EFS, Población DA, Montero R, Castro RCF. Brazilian scientific journals in surgery. III: analysis of the instructions for authors based on Vancouver uniform requirements. Acta Cir Bras. 2007;22:511-8.

27. Post SG. Encyclopedia of bioethics. 3. ed. New York: Thompson-Gale; 2004.

28. Rassi A Jr, Rassi A, Marcondes de Rezende J. American trypanosomiasis (Chagas disease). Infect Dis Clin North Am. 2012:26:275-91.

29. Rocha-e-Silva M. Impact factor, Scimago indexes and the Brazilian journal rating system: where do we go from here? Clinics (São Paulo) 2010;65:351-5.

30. Sardenberg T, Muller SS, Pereira HR, Oliveira RA, Hossne WS. Análise dos aspectos éticos da pesquisa em seres humanos contidos nas Instruções aos Autores de 139 revistas científicas brasileiras. Rev Assoc Med Bras. 1999;45:295-302.

31. Sardenberg T, Muller SS, Pereira HR, Oliveira RADE, Hossne WS. Análise dos aspectos éticos da pesquisa em seres humanos contidos nas instruções aos autores de 38 revistas de ortopedia e traumatologia. Acta Ortop Bras. 2002;10:15-8.

32. Taljaard M, McRae AD, Weijer C, Bennett C, Dixon S, Taleban J, et al. Inadequate reporting of research ethics review and informed consent in cluster randomized trials: review of random sample of published trials. BMJ. 2011;342:d2496.

33. Tavares-Neto J, Azevêdo ES. Destaques éticos nos periódicos nacionais das áreas médicas. Rev Assoc Med Bras. 2009;55:400-4.

34. Tenório MCM, Bezerra J, Tassitano RM, Barros MVG, Costa AM. Ética na pesquisa com seres humanos: revisão dos artigos publicados na Revista Paulista de Educação Física (1996-2004). Rev Bras Educ Fís Esp. 2005;19:329-35.

35. World Health Organization. Ethics and infectious disease. [Cited: 2010 Jan 10]. Available from: http://www.who.int/bulletin/volumes/86/8/08-056242/en/

36. World Medical Association. Declaration of Helsinki. Ethical principles for medical research involving human subjects. [Cited: 2012 Sept 12]. Available from: http:// www.wma.net/en/30publications/10policies/b3/index.html

Received: 15 July 2012

Accepted: 16 October 2012 


\section{Revista do Instituto de Medicina Tropical de São Paulo on line.}

Publications from 1987 to the present data are now available on:

http://www.scielo.br/rimtsp

PAST ISSUES 1959-1989 (PDF)

www.imt.usp.br/portal/

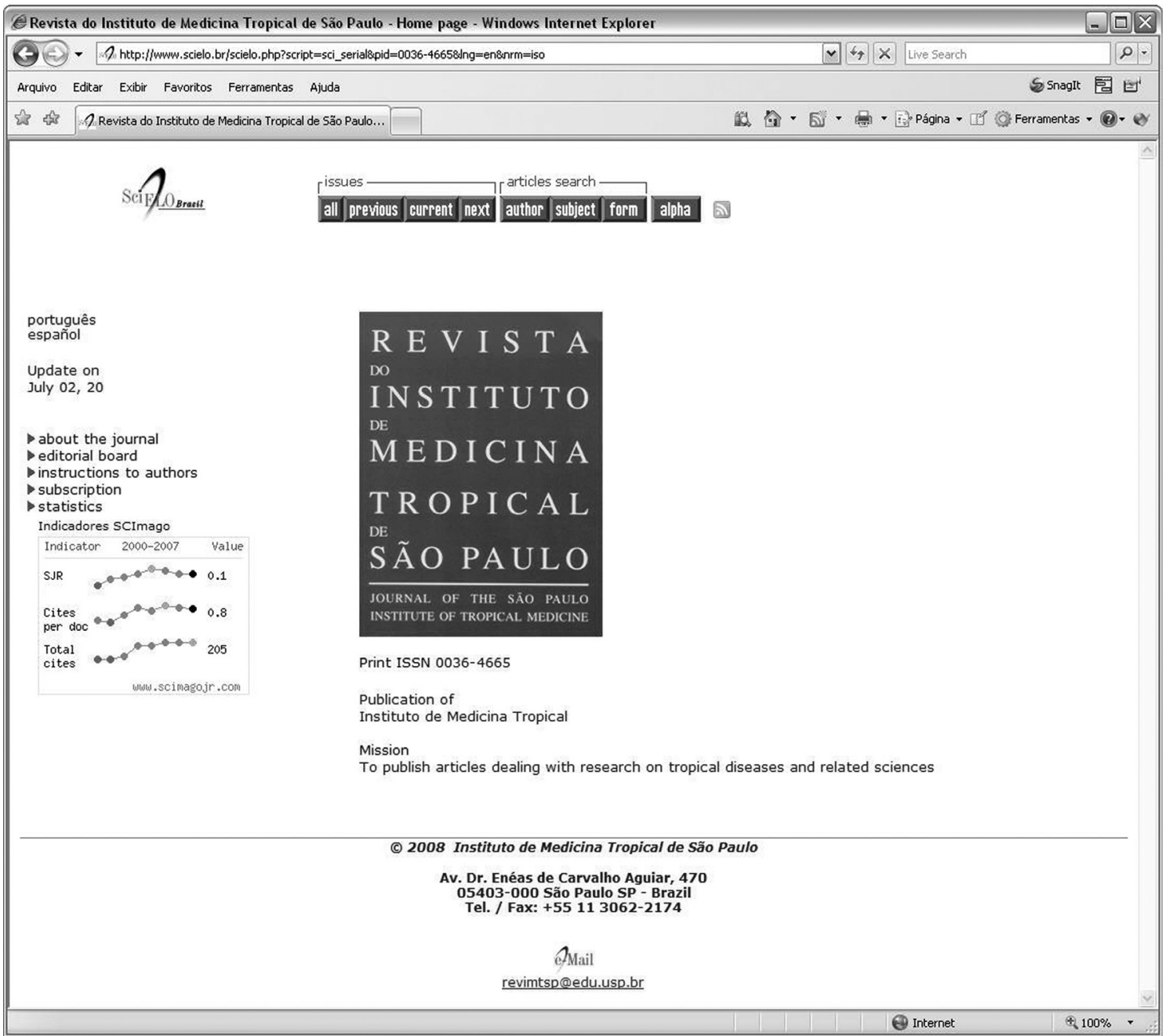

SciELO - The Scientific Electronic Library OnLine - SciELO is an electronic virtual covering a selected collection of Brazilian scientific journals.

The library is an integral part of a project being developed by FAPESP - Fundação de Amparo à Pesquisa do Estado de São Paulo, in partnership with BIREME - the Latin American and Caribbean Center on Health Sciences Information.

SciELO interface provides access to its serials collection via an alphabetic list of titles or a subject index or a search by word of serial titles, publisher names, city of publication and subject.

The interface also provides access to the full text of articles via author index or subject index or a search form on article elements such as author names, words from title, subject and words from full text.

FAPESP/BIREME Project on Scientific Electronic Publications Latin American and Caribbean Center on Health Sciences Information

Rua Botucatu 862 - 04023-901 São Paulo, SP - Brazil

Tel. (011) 5576-9863

scielo@bireme.br 